\title{
Pellets recovered from stick nests and new diet items of Furnariidae (Aves: Passeriformes)
}

\author{
Paola N. Turienzo \& Osvaldo R. Di IORIO \\ Entomología, Departamento de Biodiversidad y Biología Experimental. Facultad de Ciencias Exactas y Naturales. \\ $4^{\circ}$ Piso, Pabellón II, Ciudad Universitaria C1428EHA, Buenos Aires, Argentina; e-mails: paolaturienzo@yahoo.com; \\ megacyllene@yahoo.com.ar
}

\begin{abstract}
This is the first record showing eleven species in seven genera of Furnariidae (Aves: Passeriformes) from Argentina that regurgitate pellets. A total of 627 nests of Furnariidae was examined, and from 84 nests (13.3\%), 1,329 pellets were recovered. These pellets were found in the closed, domed nests of many Furnariidae, because in comparison to other passerine birds, their nests were used for roosting, especially in the subfamily Synallaxinae. Anumbius annumbi had the highest percentage of nests containing pellets. Food items identified from the pellets provided important new data on the diets of several species of Furnariidae.
\end{abstract}

Key words: Passerines; ovenbirds; regurgitation; prey; diet; Argentina

\section{Introduction}

A regurgitated pellet consists of undigested food material, sequestered in the gizzard, compacted, and expelled through the mouth in the form of a spherical or oval corpse (Glue 1985; Jordan 2005; Wang et al. 2009). In general, regurgitated pellets were found on the ground below the roosts of adult birds, below nests if the young produced them, and from cage bottoms with captive birds (Townsend 1918; Lamore 1958; Rhoades \& Duke 1975; Duke 1977; Stiehl \& Trautwein 1991; Wang et al. 2009, etc).

A total of 317 species of birds is known to cast pellets, of which 129 (41\%) belong to Falconiformes (including Accipitridae, see Remsen et al. 2012), and Strigiformes (Hansen 1977). These numbers came from Hansen's' list (Hansen D.E. 1977. List of species known to eject pellets. Int. Bird Pellet Study Group Bull. 7; G.E. Duke, pers. comm., mentioned in: Wilson Bull. 96 (3), 1984, pp. 470-471), and were later repeated by Below (1979), Glue (1985), and Wang et al. (2009). Elpers \& Knight (2007), following Tucker (1944) and Glue (1985) mentioned that 330 bird species belonging to more than 60 families produced pellets. Currently, Hansen's' list is largely unavailable, thus a tentative list of non-raptorial birds that produce pellets is summarised in Table S1 (see supplementary materials).

Regurgitated pellets were recorded in 15 orders of birds (Fig. 1), and in 150 species of 43 families, from which 61 species of 19 families belong to Passeriformes (Table S1, see supplementary file). In the Furnariidae, there was a single mention by Sick (2001), who wrote "os Furnarídeos cospem pelotas contendo quitina
(Lochmias)". Remsen's (2003) review of the Furnariidae did not mention pellet regurgitation.

Pellets containing mostly insect remains in the nests of 11 species of Furnariidae (Table 1) were found during the sampling of the arthropod fauna in birds' nests from Argentina (Turienzo \& Di Iorio 2008a, b, 2010, 2013, 2014). Therefore, the main scope of this contribution, for the first time will provide information about regurgitated pellets in these species of Furnariidae. This information may be used as a new tool in the study of food items in this bird family, and additonally to discuss the presence of pellets inside their nests in relationship to the use of the nests for roosting by both immature and adult birds.

\section{Material and methods}

Identifications of nests and birds were based on De la Peña (1987, 2005), Narosky \& Yzurieta (2003), and Narosky et al. (1983). Each nest was carefully removed, bagged, and taken to the laboratory, where it was dissected. At this time, all live and dead insects were removed and preserved. Several insect species used the nests for shelter during unfavourable weather conditions such as during winter and/or hot summers. Many dead insects found in the nests, were accidentally dropped by the adult birds, or delivered to their nestlings, but not consumed (Turienzo \& Di Iorio 2008a). Other materials found in the nests were also preserved, such as dead nestlings, wires, paper fragments, owl pellets, bone, plastic debris, even small stones.

Pellets were measured with a dial caliper (precision $0.01 \mathrm{~mm}$ ) and weighed (We) with an analytical balance (precision $\pm 1 \mathrm{mg}$ ). Measurements were taken between both poles (Le, length) and in the medial zone, a greater width (Wi) and a smaller thickness (Th). In some cases, when an 


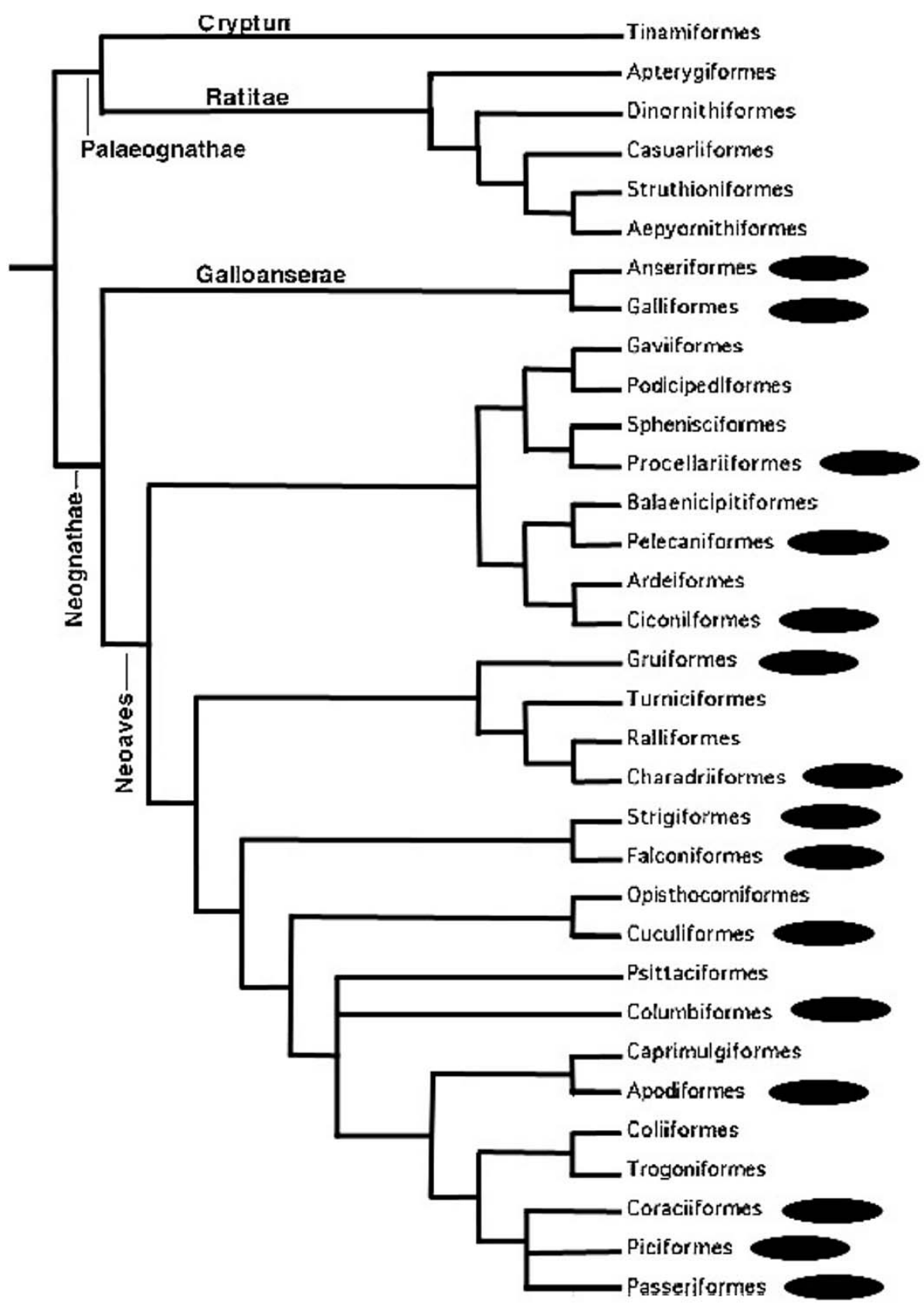

Fig. 1. Phylogeny of birds' orders and production of regurgitated pellets (black ovals). For families and species see Table S1 (except raptorial birds).

insect fragment was protruding from a pellet, measurements were taken on the general contour of the pellet, excluding the insect fragment. Particular features of some pellets and prey items are indicated in the text using a figure number, and a numerical identifier, ordered from top to bottom, and as letters from left to right, i.e., the third pellet of the top row in Figure 2 is identified as to Fig. 2: 1c.

Food items in the literature summary, were based mainly on stomach contents, supplemented by direct observations of the birds in Argentina (Marelli 1919; Aravena 1928; Zotta 1936, 1940; Olrog 1956; Klimaitis 1993; Haro 1998; Ordano et al. 1999; Alessio et al. 2005; Di Giácomo 2005; Heredia et al. 2010; De la Peña 2011), Brazil (Moojen et al. 1941; Schubart et al. 1965; Lopes et al. 2003, 2005a, b), and Chile (McFarland \& Loo 1974). For example, if a prey item was mentioned by Moojen et al. (1941) and De la
Peña (2011), it means that it was consumed in both places, Brazil and Argentina respectively, but localities and data of the examined birds may be seen in the respective references. When identified from the pellets (Figs 2-6), the food items were briefly summarized for each species.

Total pellets per bird species (Table 1 ) and numbers of pellets per nest (Table S2, see supplementary file) were slightly underestimated, because fragments present in the nests were not measured or counted. Identifications of prey insects were done in both fragmented and intact pellets by direct observation (Figs 2-6). As there are no literature accounts for the identification of insect fragments in vertebrate diets, they were identified by the following methods: 1) the use of intact specimens from regional collections (museum, private collections, etc.) and 2) the expertise of local entomologists with a good knowledge of insect fauna of each 
Table 1. Nests of Furnariidae from Argentina with regurgitated pellets found inside.

\begin{tabular}{|c|c|c|c|c|c|c|c|}
\hline Species & $\begin{array}{l}\text { No. of examined } \\
\text { nests }\end{array}$ & $\begin{array}{l}\text { Nests with } \\
\text { pellets }\end{array}$ & $\begin{array}{l}\% \text { nests } \\
\text { with pellets }\end{array}$ & $\begin{array}{l}\text { Mean pellets } \\
\text { per nest }\end{array}$ & $\begin{array}{l}\text { Range } \\
\text { Min-Max }\end{array}$ & $\begin{array}{c}\text { Total } \\
\text { pellets }\end{array}$ & $\begin{array}{l}\% \text { of total } \\
\text { pellets }\end{array}$ \\
\hline Anumbius annumbi (Vieillot, 1817) & 90 & 46 & 51.1 & $20.8 \pm 23.0$ & $1-126$ & 938 & 70.5 \\
\hline Coryphistera alaudina Burmeister, 1860 & 37 & 8 & 21.6 & $19.0 \pm 24.2$ & $1-66$ & 152 & 11.4 \\
\hline Phacellodomus ruber (Vieillot, 1817) & 43 & 9 & 20.9 & $11.1 \pm 7.9$ & $1-23$ & 100 & 7.52 \\
\hline $\begin{array}{l}\text { Phacellodomus striaticeps } \\
\text { (D'Orbigny \& Lafresnaye, 1838) }\end{array}$ & 4 & 4 & 100.0 & $18.0 \pm 18.3$ & $5-31$ & 36 & 2.71 \\
\hline Phacellodomus sp. & 14 & 2 & 14.2 & $14.0 \pm 1.4$ & $13-15$ & 28 & 2.11 \\
\hline Pseudoseisura lophotes (Reichenbach, 1853) & 54 & 2 & 3.7 & $11.0 \pm 2.8$ & $9-13$ & 22 & 1.65 \\
\hline $\begin{array}{l}\text { Phacellodomus striaticollis } \\
\quad \text { (D'Orbigny \& Lafresnaye, 1838) }\end{array}$ & 13 & 4 & 30.7 & $5.2 \pm 6.1$ & $1-14$ & 21 & 1.58 \\
\hline Furnarius rufus (Gmelin, 1788) & 310 & 4 & 1.2 & $4.7 \pm 5.5$ & $1-13$ & 19 & 1.43 \\
\hline Phacellodomus sibilatrix Sclater, 1859 & 2 & 1 & 50.0 & - & - & 8 & 0.60 \\
\hline Schoeniophylax phryganophilus (Vieillot, 1817) & 8 & 2 & 25.0 & $1.5 \pm 0.7$ & $1-2$ & 3 & 0.22 \\
\hline Asthenes dorbygni (Reichenbach, 1853) & 20 & 2 & 10.0 & $1.0 \pm 0.0$ & - & 2 & 0.15 \\
\hline $\begin{array}{l}\text { Pseudoasthenes sp. } \\
\quad \text { [prob. P. patagonica (D' Orbigny, 1839)] }\end{array}$ & 1 & - & - & - & - & - & - \\
\hline Cranioleuca pyrrhopia (Vieillot, 1818) & 13 & - & - & - & - & - & - \\
\hline Furnarius cristatus Burmeister, 1888 & 14 & - & - & - & - & - & - \\
\hline Synallaxis sp. & 3 & - & - & - & - & - & - \\
\hline Synallaxis sp. [prob. S. spixi Sclater, 1856] & 1 & - & - & - & - & - & - \\
\hline Total & 627 & 84 & - & - & - & 1329 & - \\
\hline
\end{tabular}

geographic area these specimens were found in (see for example, the section "Dead insects found inside the nests" in Turienzo \& Di Iorio 2011). The Mollusca (Gastropoda) were identified by Sergio Miquel (Museo Argentino de Ciencias Naturales "Bernardino Rivadavia", Buenos Aires, Argentina).

Bird classification and current nomenclature were taken from the American Ornithologists' Union (1998, 2000), Banks et al. (2004), Remsen et al. (2012), and the Comitę Brasileiro de Registros Ornitológicos (2007). Subspecific taxa not treated in these lists, were updated from Peterson (2002). The list in Table S1 follows the order given by the American Ornithologists' Union (1998, 2000). For ease of reading, species were alphabetically ordered within each family.

For statistical comparisons, the $H$ test of Kruskal \& Wallis was performed using the program R ( R Development Core Team 2011), because a normal distribution of the data cannot be safely assumed. If significant differences $(P<0.05)$ were found, the Nemenyi test implemented in the coin package (Hothorn et al. 2008) was applied to show which variables differed. Only two species were not compared (Table 3), due to the numbers of pellets, e.g., fewer than 10 (Table 1$)$.

Abbreviations of Argentinian provinces used in tables and supplementary files:

BA - Buenos Aires; Cb - Córdoba; Ch - Chaco; CM Buenos Aires (Campo de Mayo); ER - Entre Ríos; LP - La Pampa; Sa - Salta; SE - Santiago del Estero; SF - Santa Fe; SL - San Luis; Tu - Tucumán.

Abbreviations for the vertebrate inquilines found inside Furnariidae nests (Table S2):

$\mathrm{Ab}$ - Agelaioides badius badius (Vieillot, 1819) (Aves: Icteridae); Da - Didelphis albiventris (Lund, 1842) (Mammalia: Didelphidae); Gg - Graomys griseoflavus (Waterhouse, 1837) (Mammalia: Rodentia: Cricetidae); Hir - unidentified nest of Hirundinidae (Aves); Inq - inquiline nest of an unidentified bird; Mmc - Myiopsitta monachus catita (Jardine \& Selby, 1830) (Aves: Psittacidae); Mmm - Myiop- sitta monachus monachus (Boddaert, 1783) (Aves: Psittacidae); Mms - Myiodynastes maculatus solitarius (Vieillot, 1819) (Aves: Tyrannidae); Mr - Machetornis rixosus (Vieillot, 1819) (Aves: Tyrannidae); Of - Oligoryzomys flavescens (Waterhouse, 1837) (Mammalia: Rodentia: Muridae); Pc - Progne chalybea domestica (Vieillot, 1817) (Aves: Hirundinidae); Pd - Passer domesticus (L., 1758) (Aves: Passeridae); Pp - Phylodrias patagoniensis (Girard, 1864) (Squamata: Colubridae); Ro - unidentified rodent (Mammalia: Rodentia); Sfp - Sicalis flaveola pelzelni Sclater, 1872 (Aves: Emberizidae); Sv - Sturnus vulgaris L., 1758 (Aves: Sturnidae); Ta - Troglodytes aedon Vieillot, 1809 (Aves: Troglodytidae); Tc - Thylamys citellus (Thomas, 1912) (Mammalia: Didelphidae); Tp - Thylamys pallidior (Thomas, 1902) (Mammalia: Didelphidae).

\section{Results and species accounts}

Of 627 nests examined (Table 1, Table S2), only 84 nests $(13.3 \%)$ had pellets $(n=1329)$ in their breeding chambers (Table 1 ). The pellets were mostly ovate, with one pole more acute than the other (Figs 2-6). The difference Wi-Th ranged from 0.0 (cylindrical) to $2.9 \mathrm{~mm}$ (depressed) (Table 2).

\section{Anumbius annumbi (Fig. 2)}

Of all pellets collected, $70.3 \%$ were from this species, which had them in $51.1 \%$ of its nests (Table 1, Table S2). Measurements of pellets (Table 2) did not differ significantly from those of Coryphistera alaudina, Phacellodomus striaticeps or P. striaticollis (except by We in the last two species); however, they differ significantly in three variables from those of $P$. ruber, and in all variables from those of Furnarius rufus and Pseudoseisura lophotes (Table 3). Out of the total of 21 cylindrical pellets $(\mathrm{Wi}=\mathrm{Th}), 15$ were from $A$. annumbi, and two were flattened $(\mathrm{Wi}-\mathrm{Th}=3.7$ and $5.6 \mathrm{~mm})$. 
Table 2. Measurements of regurgitated pellets in nine species of Furnariidae (Aves) from Argentina.

\begin{tabular}{|c|c|c|c|c|}
\hline Lenght & $n$ & Mean $\pm \mathrm{SD}$ & Min & $\operatorname{Max}$ \\
\hline Furnarius rufus & 19 & $10.92 \pm 2.54$ & $6.4(8.6)$ & $14.8(16.2)$ \\
\hline Pseudosaeisura lophotes & 22 & $10.76 \pm 2.17$ & $7.4(8.6)$ & $14.2(16.0)$ \\
\hline Phacellodomus ruber & 98 & $9.46 \pm 2.06$ & 4.0 & 16.5 \\
\hline Coryphistera alaudina & 155 & $9.11 \pm 1.75$ & $4.3(5.3)$ & 14.7 \\
\hline Anumbius annumbi & 920 & $8.96 \pm 1.82$ & 5.0 & 16.6 \\
\hline Phacellodomus striaticeps & 34 & $8.94 \pm 1.72$ & 6.0 & 12.5 \\
\hline Asthenes dorbignyi & 2 & $8.15 \pm 0.63$ & 7.7 & 8.6 \\
\hline Schoeniophylax phryganophilus & 3 & $8.07 \pm 1.33$ & 6.6 & 9.2 \\
\hline Phacellodomus striaticollis & 20 & $7.89 \pm 1.47$ & $(5.9) 6.4$ & 10.5 \\
\hline Width & $n$ & Mean $\pm \mathrm{SD}$ & Min & $\operatorname{Max}$ \\
\hline Pseudoseisura lophotes & 22 & $7.02 \pm 1.15$ & $4.0(5.7)$ & 9.0 \\
\hline Furnarius rufus & 19 & $6.98 \pm 1.17$ & $3.9(5.3)$ & 8.8 \\
\hline Phacellodomus ruber & 98 & $6.07 \pm 0.79$ & 4.0 & 8.6 \\
\hline Anumbius annumbi & 920 & $5.62 \pm 0.70$ & 3.5 & $8.4(10.8)$ \\
\hline Coryphistera alaudina & 155 & $5.60 \pm 0.82$ & 3.6 & $7.0(9.0 ; 10.3)$ \\
\hline Phacellodomus striaticeps & 34 & $5.32 \pm 0.64$ & (3.7) 4.3 & 6.8 \\
\hline Phacellodomus striaticollis & 20 & $5.01 \pm 0.81$ & 3.8 & 7.0 \\
\hline Schoeniophylax phryganophilus & 3 & $5.20 \pm 0.34$ & 5.0 & 5.6 \\
\hline Asthenes dorbignyi & 2 & $4.85 \pm 0.07$ & 4.8 & 4.9 \\
\hline Thickness & $n$ & Mean $\pm \mathrm{SD}$ & Min & $\operatorname{Max}$ \\
\hline Furnarius rufus & 19 & $5.78 \pm 1.00$ & (2.8) 4.9 & 7.3 \\
\hline Pseudoseisura lophotes & 22 & $5.61 \pm 0.85$ & $(3.2) 4.7$ & 7.0 \\
\hline Phacellodomus ruber & 98 & $5.17 \pm 0.75$ & 3.0 & $6.6(7.4)$ \\
\hline Schoeniophylax phryganophilus & 3 & $4.66 \pm 0.57$ & 4.0 & 5.0 \\
\hline Anumbius annumbi & 920 & $4.66 \pm 0.63$ & 3.0 & 7.1 \\
\hline Coryphistera alaudina & 155 & $4.53 \pm 0.63$ & 2.8 & 6.4 \\
\hline Phacellodomus striaticeps & 34 & $4.43 \pm 0.63$ & 3.0 & 5.7 \\
\hline Phacellodomus striaticollis & 20 & $4.35 \pm 0.71$ & 3.3 & 5.5 \\
\hline Asthenes dorbignyi & 2 & $4.35 \pm 0.49$ & 4.0 & 4.7 \\
\hline Difference width-thickness & $n$ & Mean $\pm \mathrm{SD}$ & $\operatorname{Min}$ & $\operatorname{Max}$ \\
\hline Pseudoseisura lophotes & 22 & $1.41 \pm 0.61$ & 0.4 & 2.7 \\
\hline Furnarius rufus & 19 & $1.2 \pm 0.75$ & (0.1) 0.3 & 2.9 \\
\hline Coryphistera alaudina & 155 & $1.06 \pm 0.69$ & 0.1 & $2.8(4.0 ; 6.6)$ \\
\hline Anumbius annumbi & 920 & $0.95 \pm 0.52$ & 0.1 & $2.9(3.7 ; 5.6)$ \\
\hline Phacellodomus ruber & 98 & $0.89 \pm 0.48$ & 0.1 & $1.8(2.3)$ \\
\hline Phacellodomus striaticeps & 34 & $0.88 \pm 0.39$ & 0.2 & 1.8 \\
\hline Phacellodomus striaticollis & 20 & $0.78 \pm 0.71$ & 0.2 & $1.8(3.2)$ \\
\hline Schoeniophylax phryganophilus & 3 & $0.53 \pm 0.50$ & 0.6 & 1.0 \\
\hline Asthenes dorbignyi & 2 & $0.50 \pm 0.42$ & 0.2 & 0.8 \\
\hline Weight (gr.) & $n$ & Mean $\pm \mathrm{SD}$ & Min & $\operatorname{Max}$ \\
\hline Furnarius rufus & 19 & $0.105 \pm 0.047$ & 0.0238 & 0.2072 \\
\hline Pseudoseisura lophotes & 22 & $0.092 \pm 0.052$ & 0.0200 & 0.1892 \\
\hline Phacellodomus ruber & 98 & $0.082 \pm 0.039$ & 0.0118 & 0.2256 \\
\hline Phacellodomus striaticeps & 34 & $0.057 \pm 0.025$ & 0.0187 & 0.1218 \\
\hline Anumbius annumbi & 920 & $0.057 \pm 0.024$ & 0.0103 & 0.1965 \\
\hline Coryphistera alaudina & 155 & $0.055 \pm 0.023$ & 0.0101 & 0.1274 \\
\hline Phacellodomus striaticollis & 20 & $0.051 \pm 0.032$ & 0.0174 & 0.1509 \\
\hline Schoeniophylax phryganophilus & 3 & 0.048 & 0.0484 & 0.0644 \\
\hline Asthenes dorbignyi & 2 & $0.036 \pm 0.001$ & 0.0359 & 0.0375 \\
\hline
\end{tabular}

Explanations: All measurements in $\mathrm{mm}$; isolated values are given between parenthesis. All means are ordered by decreasing values.

In the remaining pellets, the difference $\mathrm{Wi}-\mathrm{Th}$ ranged between 0.1 and $2.9 \mathrm{~mm}$ (Table 2).

Anumbius annumbi used its old and new nests for roosting, including the abandoned nests of other pairs in its own species (Nores 1993; Fraga pers. com. in Areta \& Bodrati 2007). Additionally, it was not uncommon for the same breeding pair to reuse their nests in the same breeding season for a second clutch (Turienzo \& Di Iorio 2008).

Food items that have been identified from stomach contents of $A$. annumbi were: Insecta: Coleoptera (Marelli 1919; Aravena 1928); Curculionidae (Zotta 1936); Scarabaeidae: Aphodiinae (Aravena 1928); Lepidoptera: larvae (Haro 1998); Diptera larvae (Marelli 

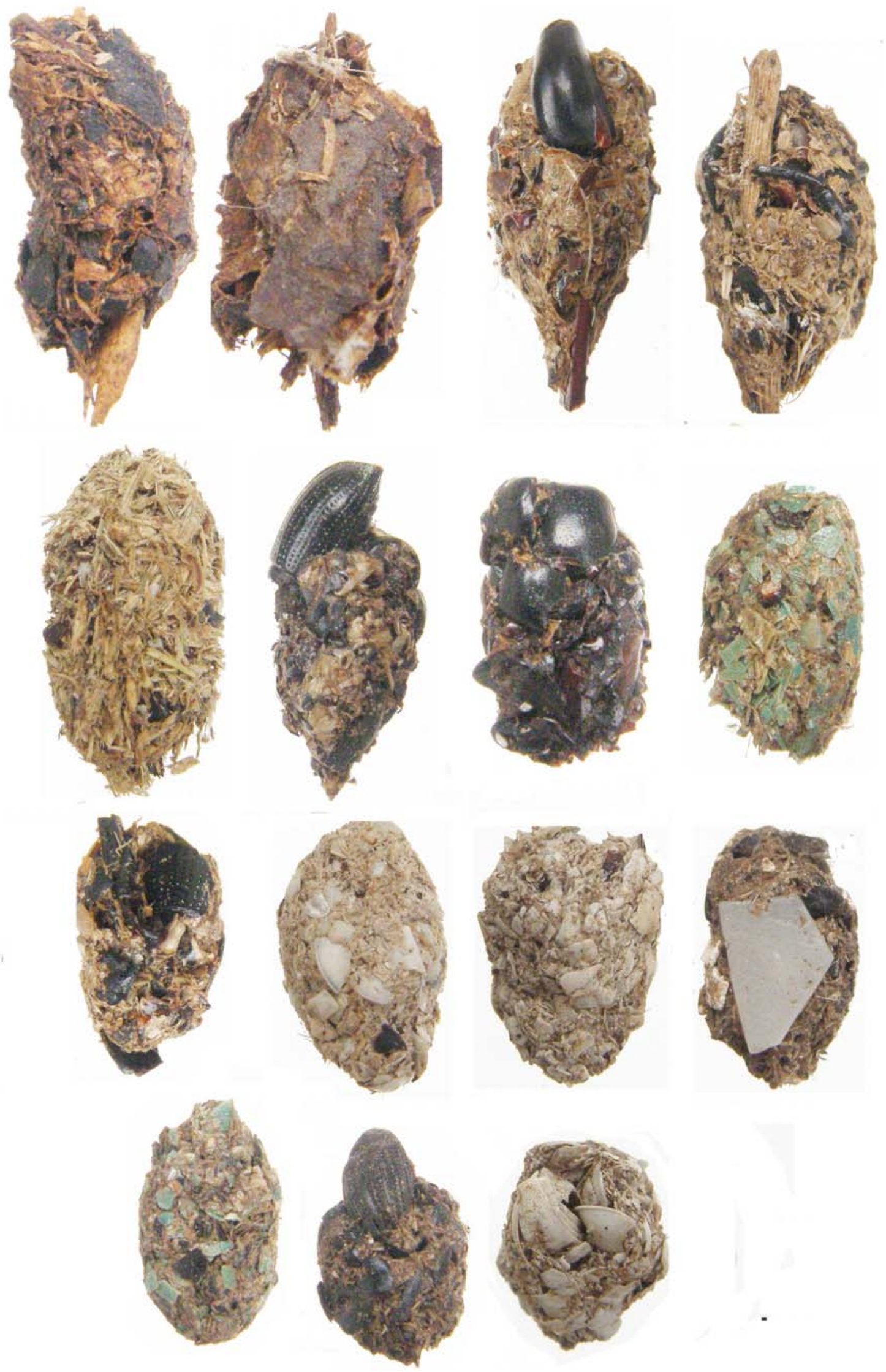

Fig. 2. Regurgitated pellets of Anumbius annumbi: 1a-b, with fragments of pods of Gleditsia triacanthos (Caesalpiniaceae); 1c, with chelycera of Lycosidae; 1d, 2a, with abundant vegetable matter; 2b, 4b, with Curculionidae; 2c, 3a, with fragments of Scarabaeidae; $2 \mathrm{~d}, 4 \mathrm{a}$, with fragments of Pentatomidae (green bugs); 3b, 3c, 4c, with sand and fragments of mollusk shells. Pellets are ordered in rows from top to bottom, indicated with a numerical identifier, and from left to right, indicated with a letter. 
Table 3. Significant differences among variables measured in regurgitated pellets of seven species of Furnariidae from Argentina (Nemenyi test, $P<0.05)$.

\begin{tabular}{|c|c|c|c|c|c|c|c|}
\hline & Ps. lophotes & F. rufus & A. annumbi & Ph. striaticollis & Ph. ruber & Ph. striaticeps & C. alaudina \\
\hline Ps. lophotes & & - & Le Wi Th We & Le Wi Th We & $\mathrm{Th} \mathrm{We}$ & $\mathrm{Wi} \mathrm{Th}$ & $\mathrm{Wi} \mathrm{Th}$ \\
\hline F. rufus & - & & Le Wi Th We & Le Wi Th We & Wi Th We & $\mathrm{Wi} \mathrm{Th}$ & $\mathrm{Th}$ \\
\hline A. annumbi & Le Wi Th We & Le Wi Th We & & We & Le Wi We & We & - \\
\hline Ph. striaticollis & Le Wi Th We & Le Wi Th We & We & & Le Wi We & - & - \\
\hline Ph. ruber & Th We & $\mathrm{Wi} \mathrm{Th} \mathrm{We}$ & Le Wi We & Le Wi We & & Wi We & $\mathrm{Wi} \mathrm{Th} \mathrm{We}$ \\
\hline Ph. striaticeps & $\mathrm{Wi} \mathrm{Th}$ & Wi Th & $\mathrm{We}$ & - & Wi We & & - \\
\hline C. alaudina & Wi Th & $\mathrm{Th}$ & - & - & $\mathrm{Wi} \mathrm{Th} \mathrm{We}$ & - & \\
\hline
\end{tabular}

Explanations: Wi - width; Th - thickness; Le - lenght; We - weight.

1919); Hemiptera (Zotta 1936; Haro 1998); animal matter $88 \%$ (Aravena 1928). Vegetable matter (Marelli 1919); 10\% (Aravena 1928); seeds (Zotta 1936; Lopes et al. 2003, following Zotta 1936); mineral matter: $2 \%$ (Aravena 1928).

Items identified in the pellets were: Insecta: Coleoptera: Carabidae; Curculionidae (Fig. 2: 2b, 4b); Naupactini; Scarabaeidae (Fig. 2: 2c); Lepidoptera: (larvae); Hymenoptera: Formicidae: Acromyrmex sp.; Solenopsis sp.; Hemiptera: Pentatomidae (Fig. 2: 2d, 4a); Arachnida: Araneae: Lycosidae (Fig. 2: 1c). Mollusca: Gastropoda: Ampullaridae (fragments). Vegetable matter (Fig. 2: 1cd, 2a, 3a); seeds and pod fragments of Gleditsia triacanthos L. (Caesalpinaceae) (Fig. 2: 1a, 1b). All pellets containing fragments of pods of G. triacanthos have very irregular shapes (Fig. 2: 1a, $1 b)$, and they were found in a single nest.

\section{Asthenes dorbignyi dorbignyi}

Only two pellets were found (Table 1), one per nest, and only in nests from Tucumán (Table S2). The pellets of A. dorbignyi were nearly the smallest in this study (Table 2). Biological data on this bird was limited (Di Iorio et al. 2010; Turienzo \& Di Iorio 2013). It is not known if the nests are used for roosting. Food items recorded in the literature were: Insecta: Hemiptera; "homopterans (including aphids)"; Diptera; Lepidoptera: [larvae and adults (including noctuids)]; Hymenoptera (McFarland \& Loo 1974); Formicidae (Remsen 2003); vegetable matter: seeds (Fjeldså \& Krabbe 1990; Remsen 2003).

\section{Coryphistera alaudina alaudina}

This species was second highest in the number of pellets found in their nests after $A$. annumbi; but these pellets were found in only eight of 37 examined nests, and with the highest physical variability of pellets per nest (Table 1, Table S2). Measurements were similar to those A. annumbi, P. striaticollis and P. striaticeps, and significantly different in several variables from those of $F$. rufus, $P$. lophotes and $P$. ruber (Table 2). One pellet was cylindrical $(\mathrm{Wi}-\mathrm{Th}=0)$, and two were flattened $(\mathrm{Wi}-\mathrm{Th}=4.0$ and $6.6 \mathrm{~mm})$.

Coryphistera alaudina roosts in its nests throughout the year, in mixed communal groups of 4 to 14 adults and young (Areta \& Bodrati 2007). Food items recorded in the literature were: Insecta: Coleoptera (Marelli 1919; Olrog 1956): Carabidae (Haro 1998);
Curculionidae (Olrog 1956; Haro 1998); Elateridae (Olrog 1956); Scarabaeidae (Haro 1998); Hymenoptera: Formicidae (Olrog 1956; Haro 1998); Orthoptera: Gryllidae (Marelli 1919); Hemiptera (Marelli 1919); Mollusca: Gastropoda (Olrog 1956). Vegetable matter: fragments of grasses (Marelli 1919); fungus (Olrog 1956).

Prey identified in the pellets were: Insecta: Coleoptera: Curculionidae: Naupactini (two species); Hemiptera: Pentatomidae; Arachnida: Scorpionida: Bothriuridae (Fig. 3: 1b, 2b); vegetable matter (Fig. 3: 1a, $2 \mathrm{a})$.

\section{Furnarius rufus}

Nineteen pellets were found in four nests $(1.2 \%)$ of F. rufus (Table 1), all collected from Buenos Aires Province (Table S2). The pellets were some of the largest found (Table 2, Fig. 4), but measurements (Table 2) did not differ significantly from those of $P$. lophotes (Table 3), however, they did differ significantly in all variables from those of $A$. annumbi and $P$. striaticollis (Table 3 ). The difference $\mathrm{Wi}$ - Th ranged between 0.3 and $2.9 \mathrm{~mm}$, with a single value of 0.1 (subcylindrical) (Table 2).

Furnarius rufus roosts in dense foliage of evergreen trees or shrubs, especially throughout the winter (Fraga 1980). There is no mention in the literature about the reuse of old nests for roosting. Out of 209 nests examined, one adult of $F$. rufus (killed by freezing temperatures), was discovered inside one old nest (Turienzo $\&$ Di Iorio 2010). The nests are sometimes reused for a second clutch in the same breeding season (Fraga 1980), as evidenced by superimposed beds inside the nests (Turienzo \& Di Iorio 2010).

Furnarius rufus is one of the most thoroughly studied Furnariidae, with the largest list of food items: Insecta: Coleoptera: Carabidae (Zotta 1936, 1940; Schubart et al. 1965; Haro 1998); Chrysomelidae (Zotta 1940; Moojen et al. 1941): Cassidinae (Zotta 1936); Curculionidae (Zotta 1940; Moojen et al. 1941; Schubart et al. 1965; Ordano et al. 1999): (Gonipterus sp.) (Haro 1998); Elateridae (Zotta 1940; Moojen et al. 1941); Histeridae (Hister sp.; Pelister sp.) (Schubart et al. 1965); Hydrophilidae (Ordano et al. 1999); Scarabaeidae: Aphodiinae (Schubart et al. 1965); Tenebrionidae (Schubart et al. 1965; Haro 1998); Lepidoptera: (larvae) (Marelli 1919; Zotta 1936; Moojen et al. 1941; Schubart et al. 1965); Hy- 

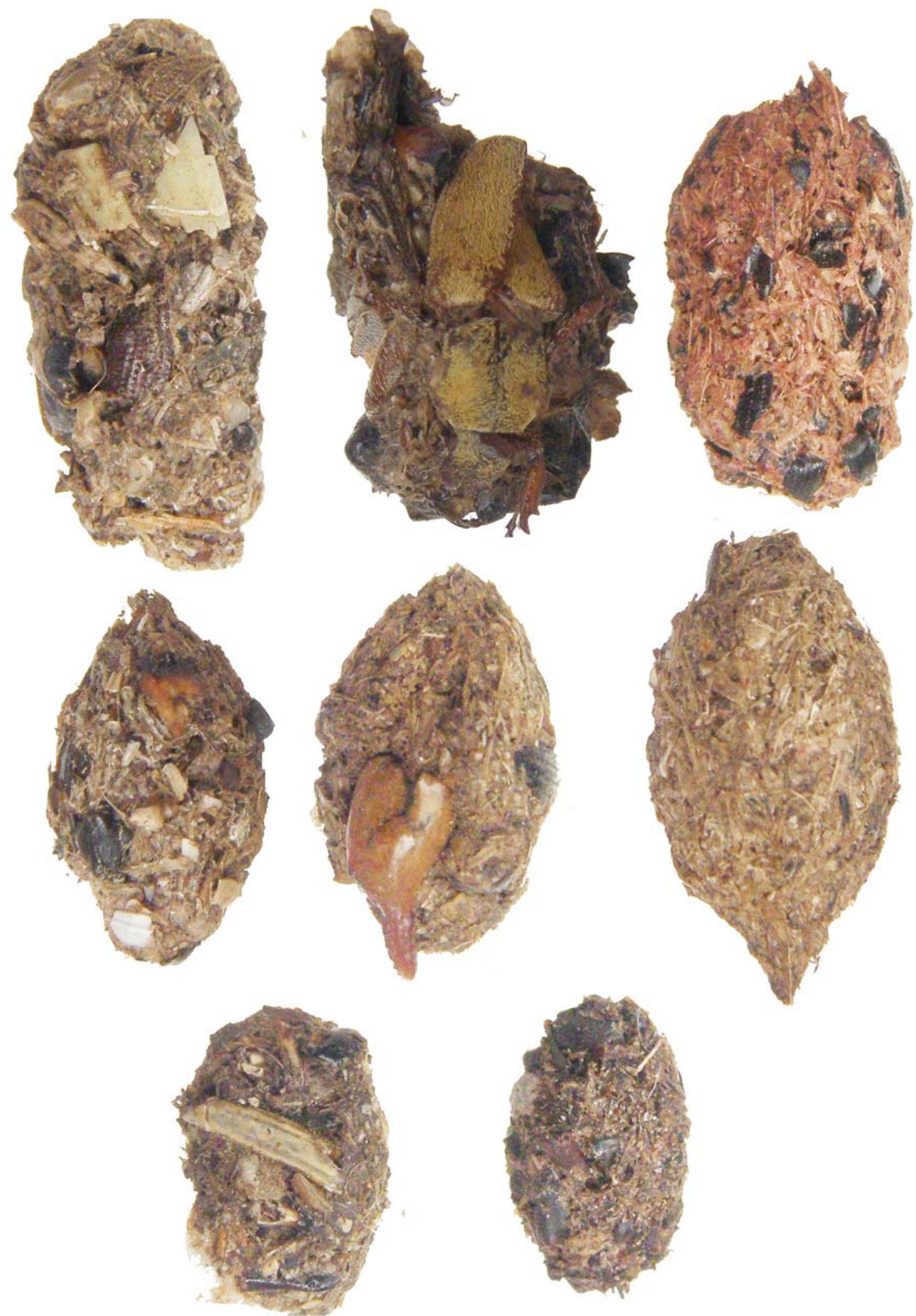

Fig. 3. Regurgitated pellets of Coryphistera alaudina: 1b, 2b, with fragments of a scorpion; 2a, 3a, with abundant vegetable matter. For further exlanations see Fig. 1.

menoptera: Chrysididae (Schubart et al. 1965); Formicidae (Moojen et al. 1941; Schubart et al. 1965; Haro 1998): Acromyrmex sp. (Zotta 1940; Ordano et al. 1999; Di Giácomo 2005), Camponotus sp. (Ordano et al. 1999); Crematogaster sp. (Zotta 1940), Pheidole sp. (Zotta 1940); Pseudomyrmex sp. (Ordano et al. 1999); Diptera (Moojen et al. 1941); Orthoptera (Moojen et al. 1941; Schubart et al. 1965): Acrididae 

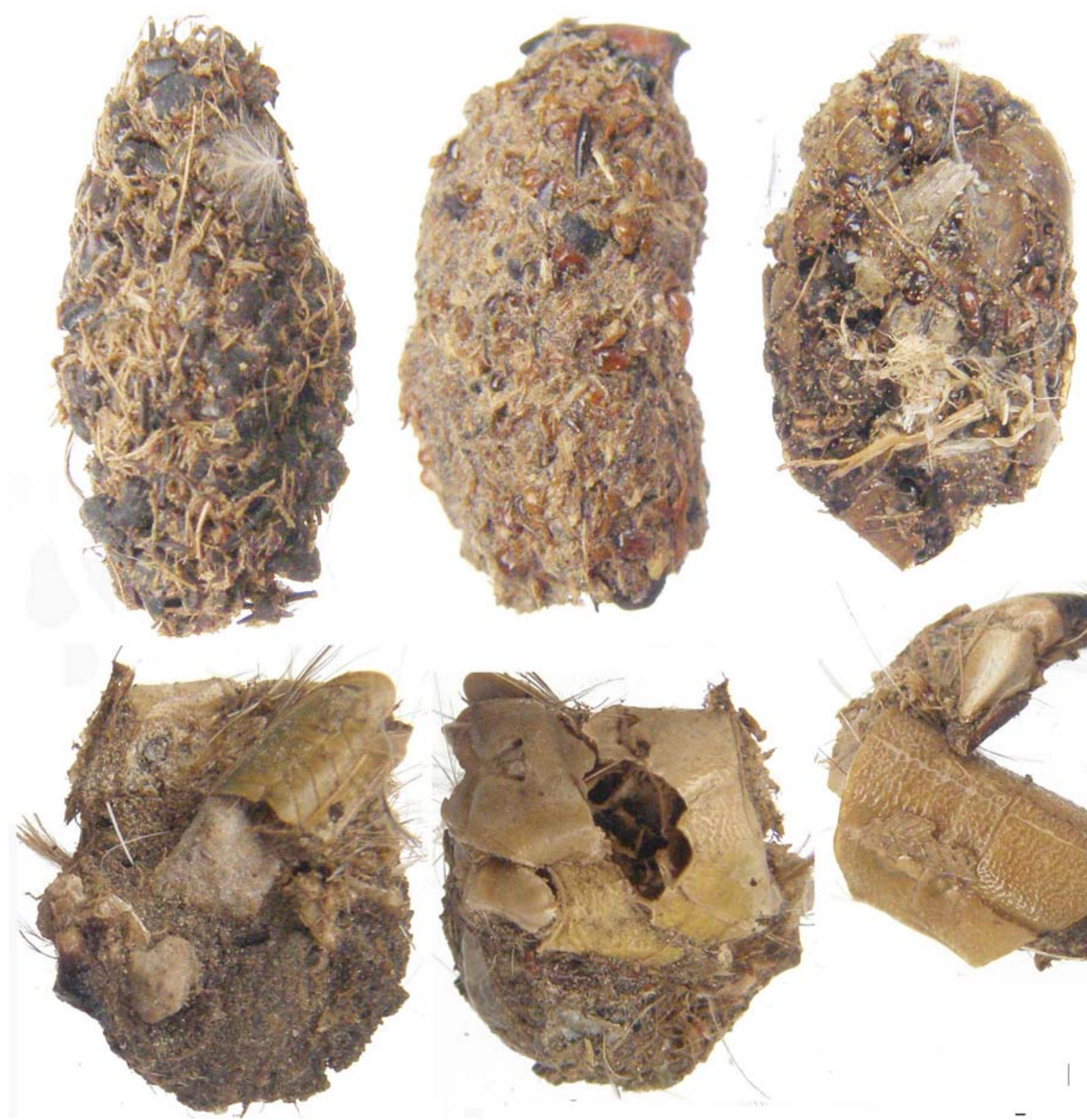

Fig. 4. Regurgitated pellets of Furnarius rufus: 1a-c, with abundant vegetable matter; 2a-c, with fragments of a grasshopper (Acrididae). For further exlanations see Fig. 1.

(Zotta 1936); Gryllidae: Gryllus argentinus (De la Peña 2011); Blattodea: Blattidae: Blatta orientalis (De la Peña 2011); Isoptera (Di Giácomo 2005); Termitidae (Schubart et al. 1965); Hemiptera (Schubart et al. 1965; Haro 1998): Cercopidae (Haro 1998); "Homoptera" (Ordano et al. 1999); Arachnida (Zotta 1936): Araneae (Schubart et al. 1965); Crustacea: Dilocarcinus pagei (Di Giácomo 2005). Mollusca: Gastropoda: Planorbidae (Planorbis sp.) (Zotta 1940). Oligochaeta (Moojen et al. 1941; De la Peña 2011); Pisces: Characidae: "mojarritas" (Astyanax sp.?) (delivered to nestlings) (Heredia et al. 2010); Amphibia: frogs (Lopes et al. 2005b); tadpoles (delivered to nestlings) (Heredia et al. 2010). Vegetable matter: seeds Solanum sp. (Solanaceae) (Ordano et al. 1999); seed, fruits of Vitex megapotamica (Lopes et al. 2003); Citrus aurantium, Psidium guajava (Lopes et al. 2003); bread (De la Peña 2011).
Few items were identified in the pellets: Insecta: Orthoptera: Acrididae (Fig. 4: 2a-c); Mollusca: Gastropoda: Ampullaridae (fragments); vegetable matter: (Fig. 4: 1a-c).

\section{Lochmias nematura}

Sick (2001) wrote no description of the pellets, nor if the birds were seen casting pellets and if the pellets were found in the nests. According to Zyskowski \& Prum (1999), L. nematura is a cavity-nesting bird, but their nests were not described.

Prey items of L. nematura in Brazil were given by Lopes et al. (2005a): Insecta: Coleoptera: larva, adult; Diptera: larva, adult; Lepidoptera: adult, larva; Hymenoptera: Formicidae; Blattaria: ootheca; Hemiptera; Arachnida: Araneae; Pseudoscorpionida; Mollusca: Gastropoda; Amphibia: Anura. Vegetable matter: seed $(2.2 \mathrm{~mm})$. 

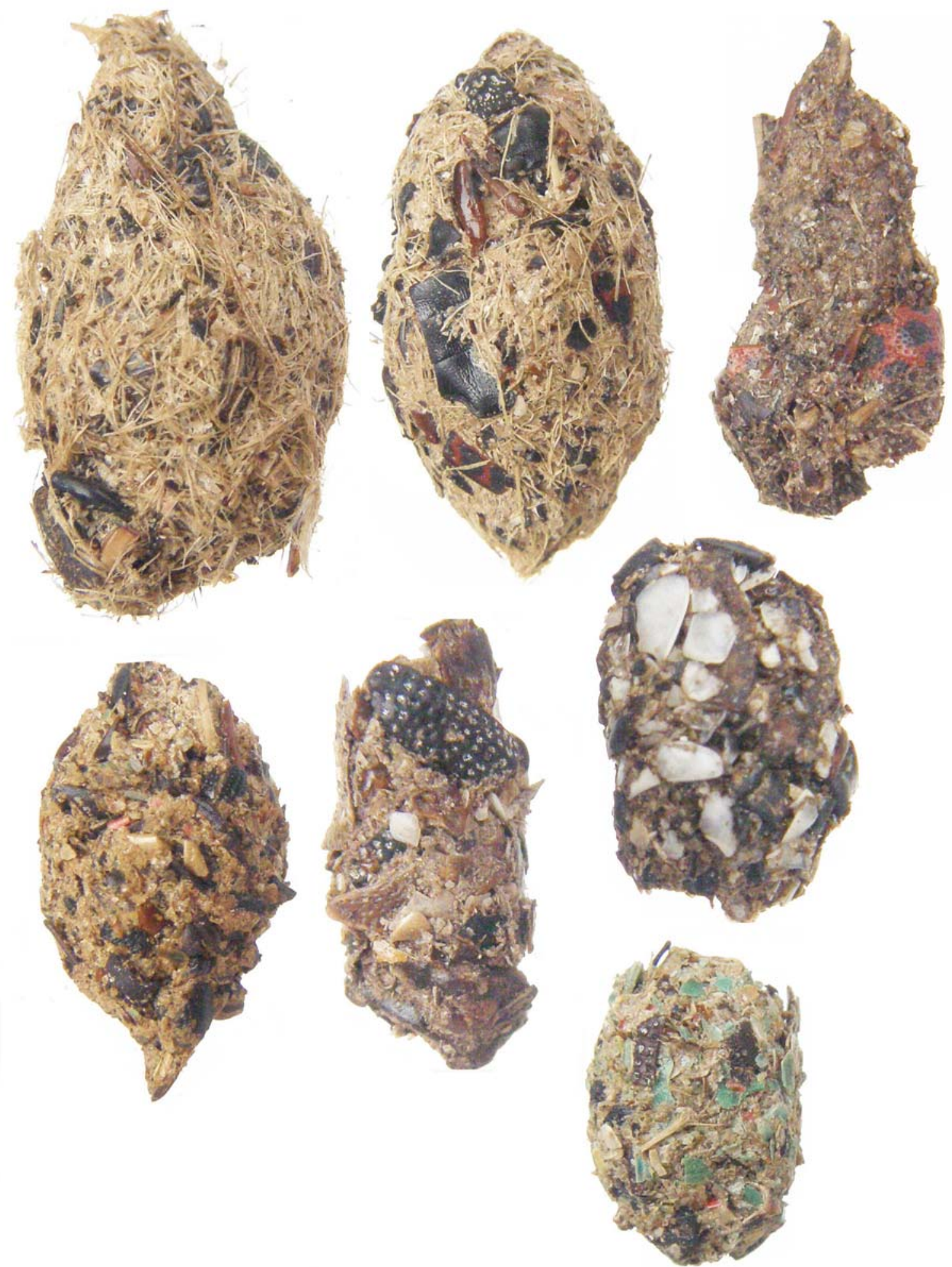

Fig. 5. Regurgitated pellets of Phacellodomus ruber: 1a, 1b, with abundant vegetable matter; 1c, with a fragment of elytrum of Chrysomelidae; 3a, fragments of cuticle of green bugs (Pentatomidae). For further exlanations see Fig. 1.

\section{Phacellodomus ruber}

Pellets of this species were the third in order of abundance found inside nests (Table 1, Table S2). Measurements (Table 2) differ significantly in two variables from those of P. striaticeps and P. lophotes (Table 3), and in three variables from the remaining species (Table 3 ). From a total of 21 cylindrical pellets, a single one was of $P h$. ruber. The difference $\mathrm{Wi}-\mathrm{Th}$ ranged between 0.1 and $1.8 \mathrm{~mm}$, with an isolated value of 2.3 (Table 2).

The nests are used as dormitories by bonded pairs during the non-breeding period (Di Giácomo 2005). Food items recorded in the literature were: Insecta: Coleoptera: Carabidae (Ordano et al. 1999; Alessio et al. 2005); Curculionidae (Alessio et al. 2005); 
Chrysomelidae (Alessio et al. 2005); Dytiscidae (Alessio et al. 2005); Elateridae (Alessio et al. 2005); Hydrophilidae (Alessio et al. 2005); Tenebrionidae (Ordano et al. 1999; Alessio et al. 2005); Lepidoptera (Alessio et al. 2005); Hymenoptera: Formicidae (Alessio et al. 2005); Camponotus sp. (Ordano et al. 1999); Pheidole sp. (Ordano et al. 1999); Diptera (Alessio et al. 2005); Hemiptera: Belostomatidae (Belostoma sp.) (Alessio et al. 2005); Corixidae (Alessio et al. 2005). Arachnida: Araneae: Lycosidae (Alessio et al. 2005); Pysauridae (Alessio et al. 2005); Opiliones: "Phalanguida" (Ordano et al. 1999). Mollusca: Planorbidae (Ordano et al. 1999); Amphibia (vertebrate) (Ordano et al. 1999); vegetable matter: Poaceae (= Graminae): unidentified seed (Alessio et al. 2005); Polygonaceae: Polygonum sp. (Alessio et al. 2005).

Food items in the pellets were identified as follows: Insecta: Coleoptera: Chrysomelidae (Fig. 5: 1c); Curculionidae; Hemiptera: Pentatomidae (Fig. 5: 2a). Vegetable matter (Fig. 5: 1a, 1b).

\section{Phacellodomus sibilatrix}

Only eight pellets were found and all in one nest (Table 1, Table S2). There are no data in literature about food items or use of the nests as roosts.

\section{Phacellodomus striaticeps striaticeps}

Measurements of pellets (Table 2) differed significantly in only two variables with respect to those of $F$. rufus, $P h$. ruber, and $P$. lophotes, and in only one variable with respect to those of $A$. annumbi, but they did not differ significantly in any variable with respect to those of $C$. alaudina (Table 3 ). One pellet was cylindrical (Wi $=\mathrm{Th}$ ).

There are no data in the literature for $P$. striaticeps regarding food items and use of the nests for roosting.

\section{Phacellodomus striaticollis striaticollis}

Pellets of Ph. striaticollis striaticollis were the third smallest of all species, except the length carried the lowest value of all measurements (Table 2). No significant differences were found with the pellets of $C$. alaudina and Ph. striaticeps, but they were significantly different in all variables with respect to the biggest pellets of $F$. rufus and $P$. lophotes, in three variables with respect to $P h$. ruber, and in one variable with respect to $A$. annumbi (Table 3). Only one pellet of $P$. striaticollis was cylindrical.

There are no data in literature about the use of the nests as roosting places for Ph. striaticollis striaticollis. Food items of this species mentioned in literature were: Insecta: Coleoptera: Chrysomelidae (Zotta 1936); Curculionidae (Zotta 1936); Elateridae (Zotta 1936); Tenebrionidae (Zotta 1936); Hemiptera: Coreidae (Zotta 1936); Pentatomidae (Zotta 1936); Orthoptera: Acrididae (Zotta 1936); Diptera (Zotta 1936).

\section{Pseudoseisura lophotes}

Twenty two pellets were found in two nests (Table 1, Table S2). These pellets were large in size (Table 2), significantly not different in any variable to $F$. rufus, but significantly different in two variables with respect to $C$. alaudina, $P$. ruber and $P$. striaticeps, and significantly different in all variables with respect to $A$. annumbi and Ph. striaticollis striaticollis (Table 3).

Bonded pairs of Pseudoseisura lophotes are known to sleep in their nests throughout the year. Prior to the egg-laying period, both members of the pair sleep together in the nest. During egg-laying, the female spends the night with the eggs, apparently incubating them. The male usually roosts near the nest in the foliage, in a penultimate nest, or occasionally in the breeding nest. Once fledged, juveniles remain in the parental territory, at first roosting in the nest where they were reared, then later in their parent's new dormitory nest (all information from Nores \& Nores 1994).

The food items mentioned in literature are: Insecta: Coleoptera (Marelli 1919); Carabidae (Aravena 1928); Chrysomelidae Poecilaspis bonariensis (Aravena 1928); Curculionidae (Zotta 1940): Gonipterus sp.; unidentified spp. (Haro 1998); Scarabaeidae (Zotta 1940); Lepidoptera: Pieridae (Haro 1998); Hymenoptera: Formicidae (Aravena 1928): Solenopsis saevissima (Haro 1998); Hemiptera (Haro 1998); Orthoptera: Acrididae: Dichroplus elongatus (Haro 1998); Aves: eggs (Lopes et al. 2005b); animal matter 80\% and 95\% (Aravena 1928). Vegetable matter: seeds (Marelli 1919; Lopes et al. 2003); black seeds (Aravena 1928); vegetable matter 5 to $20 \%$ (Aravena 1928).

Yellow material found in several pellets (Fig. 6: 1a-b, 2a), consisted of crushed pods of Prosopis caldenia Burkart (Mimosaceae). In La Pampa Province, this was the most common tree where the nests were located (Turienzo \& Di Iorio 2014).

\section{Schoeniophylax phryganophilus phryganophilus}

Only three pellets were found in two of eight examined nests (Table 1), and of these, one pellet was cylindrical.

There are no data in the literature about the use of the nests as roosts for $S$. phryganophilus phryganophilus. Food items mentioned in the literature were: Insecta: Coleoptera (Marelli 1919; Zotta 1940): Carabidae (Alessio et al. 2005); Curculionidae (Alessio et al. 2005); Chrysomelidae (Alessio et al. 2005); Dytiscidae (Alessio et al. 2005); Hydrophilidae (Zotta 1936; Alessio et al. 2005); Hymenoptera: Formicidae (Alessio et al. 2005): Pheidole sp. (Zotta 1940); Orthoptera: Acrididae (Zotta 1936, = Locustidae): Paulininae: Paulinia sp. (Alessio et al. 2005); Grillotalpidae (Alessio et al. 2005); Arachnida: Araneae: Pysauride (Alessio et al. 2005). Vegetable matter: seeds (Marelli 1919; Alessio et al. 2005).

Vertebrate inquilines in sampled nests of Furnariidae From a total of 84 nests of Furnariidae containing pellets, inquiline birds were found in 20 of them (Table S2): Passer domesticus in six nests, Myiopsitta monachus in four nests, Machetornis rixosus in three nests, Sicalis flaveola pelzelni in two nests, and unidentified birds in three nests. Rodents were found in two nests. 


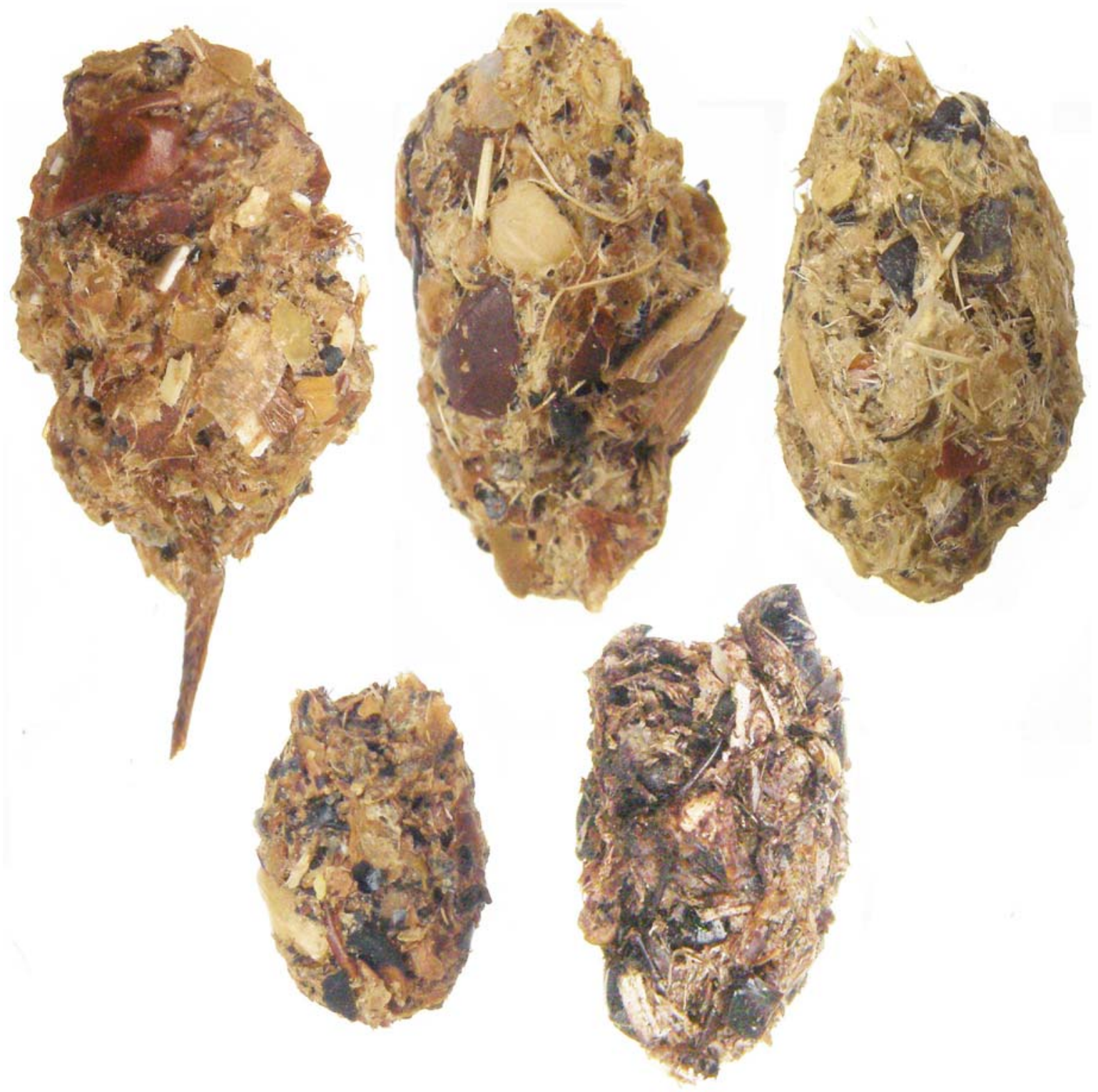

Fig. 6. Regurgitated pellets of Pseudoseisura lophotes: 1a-b, 2a, with fragments of pods of Prosopis caldenia (Mimosaceae); 1c, unidentified vegetable matter. For further exlanations see Fig. 1.

\section{Discussion}

Regarding the inquiline birds found in some nests of Furnariidae with pellets (Table S2), not one of them are known to produce pellets.

Myiopsitta monachus consumed mostly fruits, but also seeds, leaves, bark, and flowers (Ordano et al. 1999; De la Peña 2011), and is not known to produce pellets. Sicalis flaveola pelzelni is primarily granivorous (Marelli 1919; Aravena 1928; Zotta 1936, 1940; Klimaitis 1993; De la Peña 2011), but it also eats some leaves, fruits (De la Peña 2011), and insects (Marelli 1919), e.g., Curculionidae (Aravena 1928), Chrysomelidae 30\% (Zotta 1940), Diabrotica speciosa (Aravena 1928), and small Orthoptera (Aravena 1928). It is not known if $S$. f. pelzelni produces pellets, but no species of Thraupidae is known to produce them (Table S1).

In passerines, pellets were mentioned from Passer montanus (L., 1758) but not from Passer domesticus
(Table S1). The diet of P. domesticus included up to $70 \%$ insect material but also a great numbers of seeds (Marelli 1919; Aravena 1928; Zotta 1940; McFarland \& Loo 1974; Klimaitis 1993; De la Peña 2011). Pellets were not found in the nests of $P$. domesticus sampled inside the nests of Furnariidae (Table S2), nor were they found in their exteriorly built nests (Turienzo \& Di Iorio 2010).

The tyrannid Myiozetetes cayanensis (L., 1766) regurgitates the seeds and plant skin (peel) fragments after comsumption of vegetables (Carvalho 1960), but production of pellets was mentioned for other species in the family (Table S1). Machetornis rixosus is insectivorous (Alessio et al. 2005; De la Peña 2011), but is not known to produce pellets.

In summary, other species of birds that also use the nests of Furnariidae in Argentina, were found in $23.8 \%$ of nests of furnariids that were found to cast pellets. None of these other species are known to produce 


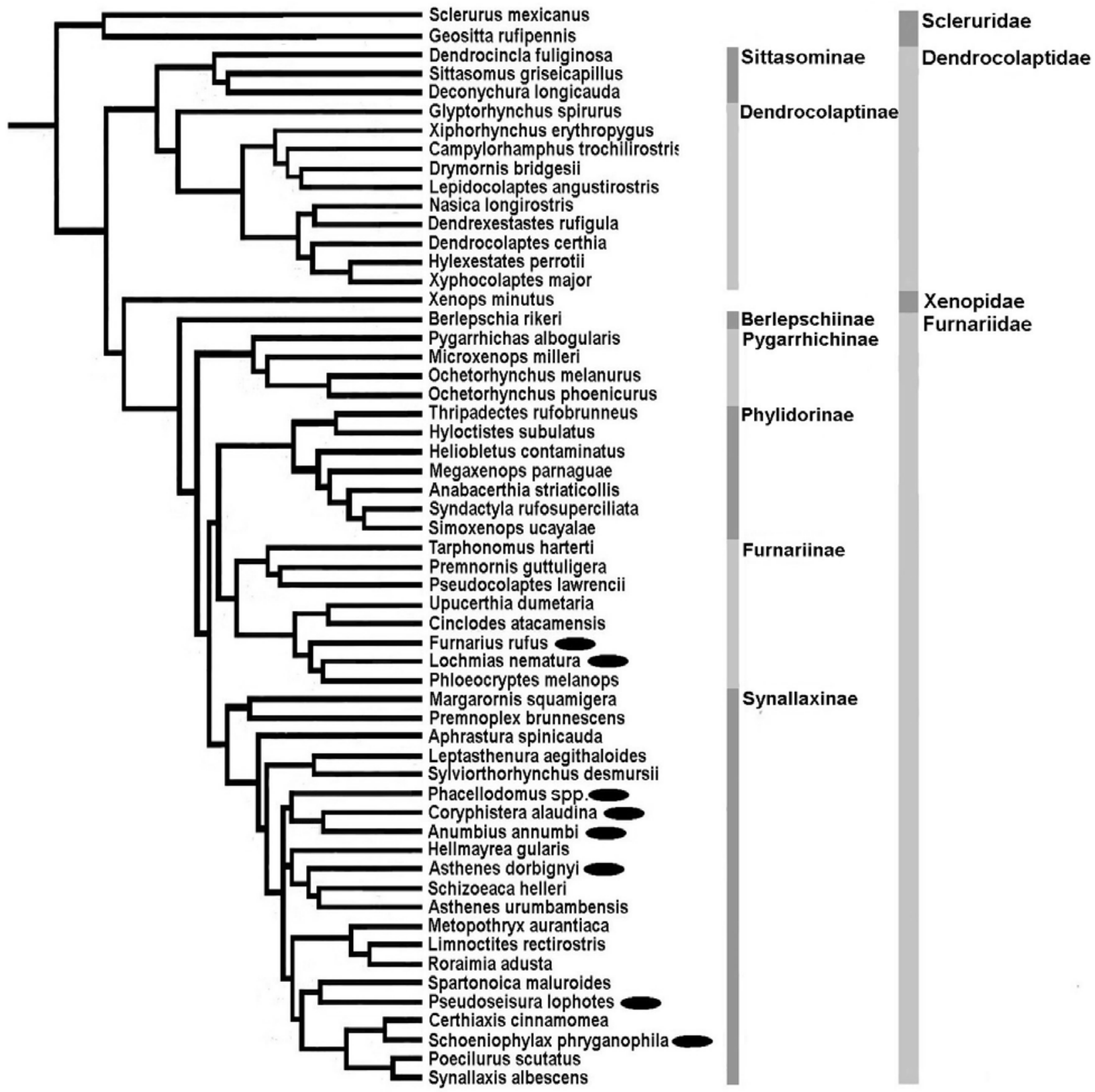

Fig. 7. Phylogeny within the Furnariidae (redrawn from Olson et al. 2013), with the genera and species that produce regurgitated pellets signaled by black ovals.

pellets. Therefore, we are confident that pellets in the nests, can be attributed to the species of Furnariidae that build and use the nests rather than birds species that subsequently use the nests.

Our searches of nests of other insectivorous birds from Argentina (Hirundinidae, Mimidae, Troglodytidae, Turdidae, Tyrannidae) have not revealed pellets. Although some species in these families have been recorded as casting pellets (Table $\mathrm{S} 1$ ), the main difference in comparison to Furnariidae is that their nests are generally cup shaped that are used only during the breeding season, and thus the pellets may be discarded or produced by these birds outside their nests.

In contrast, many species of Furnariidae use nests for roosting by the same bonded pairs or by the juvaniles co-inhabiting with their parents throughout a year or in different years (Thomas 1983; Nores 1993; Nores \& Nores 1994; Di Giácomo 2005, Areta \& Bodrati 2007; Greeney 2008). As a consecuence of the use of the nests as roosting sites by some species of Furnariidae, regurgitated pellets are found inside the nests. The great numbers of regurgitated pellets found in some nests (Table S2) may be an accumulation produced throughout a year, or during different years in which the nests were in use as dormitories.

Additionally, pellets may be used to identify prey items of Furnariidae as well as it may be used as a method with other bird species (Table S1). In most pellets, vegetable matter was mixed with insect fragments (Figs 2-6). This showed that both vegetable and insect materials were consumed simultaneously, and not in different seasons, as was stated by Lopes et al. (2003). 
A noteworthy point is the coincidence between pods of leguminose trees consumed by Furnariidae with the same trees where the nests were located, Gleditsia triacanthos for A. annumbi (Turienzo \& Di Iorio 2008a), and Prosopis caldenia for P. lophotes (Turienzo \& Di Iorio 2014).

The production of pellets in Furnariidae is probably more widespread in phylogenetically allied genera and/or species of Furnariidae (Fig. 7). For example, Lochmias nematura was the single Furnariinae previously known to produce pellets (Sick 2001), and the discovery of pellets from its sister species Furnarius rufus (Fig. 7) was accomplished here; but pellets are still not known from Furnarius cristatus Burmeister, 1888 (Table S2), or its related species Phleocryptes melanops (Vieillot, 1817) (Fig. 7). Among the Synallaxinae, pellets were found in three sister genera, Anumbius, Coryphistera and Phacellodomus, but are not known yet in Certhiaxis, the sister genus of Schoeniophylax, or in Spartonoica, the sister genus of Pseudoseisura (Fig. 7). Also the regurgitation of pellets is not yet known in any species of the recently established family Scleruridae, in the subfamily Philydorinae (Furnariidae), and in Dendrocolaptidae, that are insectivorous and cavity-nesting birds (Fig. 7).

Nevertheless, the absence of pellets in the nests of some species of Furnariidae (Table 1, Table S2) does not mean that these species do not produce pellets. In view of the low frequency of pellets in the nests of some species (Table S2), probably a more extensive nest sampling is needed. As pellets can be recovered from nests at any time of the year (Table S2), and old disused nests may be disassembled without interference with the birds.

\section{Acknowledgements}

We thank Volker Manhert for copies of the most difficult and relevant papers; Andrés Porta (UBA) for the statistical assistance; Sergio Miquel (MACN) for the identification of Gastropoda. At least, we are also sincerely and fully acknowledged to James Remsen for invaluable comments and corrections, and Gale Ridge (USA, Connecticut) for the improvement in the English usage.

\section{References}

Ashoori A. \& Zolfinejad K. 2008. The ecology of the corncrake Crex crex in stubble paddyfields in the south Caspian lowlands. Podoces 3 (1-2): 92-96.

Alessio V.G., Beltzer A.H., Lajmanovich R.C. \& Quiroga M.A. 2005. Ecología alimentaria de algunas especies de Passeriformes (Furnariidae, Tyrannidae, Icteridae y Emberizidae): consideraciones sobre algunos aspectos del nicho ecológico, pp. 441-482. In: Aceñolaza F.G. (ed.), Temas de la Biodiversidad del Litoral fluvial argentino II, INSUGEO, Miscelánea 14, Consejo Nacional de Investigaciones Científicas y Técnicas, Facultad de Ciencias Naturales e Instituto Miguel Lillo, Universidad Nacional de Tucumán, San Miguel de Tucumán, 560 pp. ISBN: 987-9390-69-5

American Ornithologists' Union. 1998. Check-list of North American Birds. The Species of Birds of North America from the Arctic through Panama, Including the West Indies and Hawaiian Islands $7^{\text {th }}$ Edition. American Ornithologists' Union. Washington DC, 829 pp. ISBN: 1-891276-00-X

American Ornithologists' Union. 2000. Forty-second supplement to the American Ornithologists' Union Check-list of North American Birds. Auk 117 (3): 847-858.

Aravena R.O. 1928. Notas sobre la alimentación de las aves. El Hornero. Revta Ornitol. Neotrop. 4 (2): 153-166.

Arcas J. 1999. Predation of Common Sandpiper Actitis hypoleucos on Orchestia gammarellus (Crustacea: Amphipoda): problems in assessing its diet from pellet and dropping analysis. Int. Wader Study Group Bull. 94: 31-33.

Areta J.I. \& Bodrati A. 2007. Historia natural y comportamiento social del Crestudo (Coryphistera alaudina). Ornitol. Neotrop. 18: 209-222.

Asokan S., Mohamed Samsoor Ali A. \& Manikannan R. 2009a. Diet of three insectivorous birds in Nagapattinam District, Tamil Nadu, India - a preliminary study. J. Threaten. Taxa 1 (6): 327-330.

Asokan S., Mohamed Samsoor Ali A. \& Manikannan R. 2009b. Preliminary investigations on diet and breeding biology of the Indian yoller Coracias benghalensis in a portion of Cauvery Delta, Tamil Nadu, India. World J. Zool. 4 (4): 263-269.

Atkinson E.C. \& Cade T.J. 1993. Winter foraging and diet composition of northern shrikes in Idaho. Condor 95: $528-535$.

Balph M.H. 1975. Development of young brewer's. The Wilson Bull. 87 (2): 207-230.

Banks R.C., Cicero C., Dunn J.L., Kratter A.W., Rasmussen P.C., Remsen Jr. J.V., Rising J.D. \& Stotz D.F. 2004. Fortyfifth supplement to the American Ornithologists' Union check-list of North American birds. Auk 121 (3): 985-995.

Barrett R.T., Camphuysen C.J., Anker-Nilssen T., Chardine J.W., Furness R.W., Garthe S., Hüppop O., Leopold M.F., Montevecchi W.A. \& Veit R.R. 2007. Diet studies of seabirds: a review and recommendations. ICES J. Mar. Sci. 64 (9): 1675-1691. DOI: 10.1093/icesjms/fsm152

Bauman C.S. 1931. Food regurgitation by young kingbirds. Wilson Bull. 43 (2): 146-147.

Beals M.V. 1931. An additional observation of food regurgitation by young kingbirds. Wilson Bull. 43 (4): 308.

Bellis G.A. \& Profke A.M. 2003. Rainbow bee-eaters (Merops ornatus) as a monitoring tool for honeybees (Apis mellifera L.; Hymenoptera: Apidae). Aust. J. Entomol. 42 (3): 266270. DOI: 10.1046/j.1440-6055.2003.00356.x

Below T.H. 1979. First report of pellet ejecting in 11 species. Wilson Bull. 91 (4): 626-628.

Bent A.C. 1942. Life histories of North American flycatchers, larks, swallows, and their allies. U.S. Nat. Mus. Bull. 179: 1-555. ISBN: 0486258319, 9780486258317

Blaber S.J.M. \& Wassenberg T.J. 1989. Feeding ecology of the piscivorous birds Phalacrocorax varius, P. melanoleucos and Sterna bergii in Moreton Bay, Australia: diets and dependence on trawler discards. Marine Biol. 101 (1): 1-10. DOI: 10.1007/BF00393473

Blanco G., Fargallo J.A. \& Cuevas J.A. 1994. Consumption rates of olives by choughs in central Spain: variations and importance. J. Field Ornithol. 65 (4): 482-489.

Bowles J.H. 1921. Nesting habits of the nighthawk at Tacoma, Wash. Auk 38 (2): 203-217. DOI: 10.2307/4073883

Carvalho C.T. de 1960. Comportamento de Myiozetetes cayanensis e notas biológicas sôbre espécies afins (Passeres, Tyrannidae). Papéis Avulsos do Departamento de Zoología, Secretaría da Agricultura, Săo Paulo 14 (15): 121-132.

Casaux R.J. 2003. On the accuracy of the pellet analysis method to estimate the food intake in the Antarctic shag, Phalacrocorax bransfieldensis. Folia Zool. 52 (2): 167-176.

Chong K.W. 2010. Asian koel regurgitates pellet. In: FeedingPlants, Pellets. http://www.besgroup.org/2010/12/12/asiankoel-regurgitation-pellet (accessed 14.02.2011)

Collazo J.A. 1985. Food habits of nesting great blue herons at Heyburn State Park, Idaho. Northwest Science 59 (2): 144146.

Comitę Brasileiro de Registros Ornitológicos. 2007. Lista das aves do Brasil. 6Ş ediçăo (16 de agosto de 2007). Comitę Brasileiro de Registros Ornitológicos, Sociedade Brasileira de Ornitologia, 32 pp. http://www.cbro.org.br (accessed 15.04.2008) 
Cornwell G.W. 1963. Observations on the breeding biology and behavior of a nesting population of belted kingfishers. Condor 65 (5): 426-431.

Cottam C. \& Williams C.S. 1939. Food and habits of some birds nesting on islands in Great Salt Lake. Wilson Bull. 51 (3): $150-155$.

Dean W.R.J. \& Milton S.J. 2000. Directed dispersal of Opuntia species in the Karoo, South Africa: are crows the responsible agents? J. Arid Environ. 45 (4): 305-314. DOI: 10.1006/jare.2000.0652

De la Peña M.R. 1987. Nidos y huevos de aves argentinas. Edición del autor. Santa Fé, 229 pp.

De la Peña M.R. 2005. Reproducción de las aves argentinas (con descripción de pichones). Monografia LOLA (Literature of Latin America), 20, pp. 1-846.

De la Peña M.R. 2011. Observaciones de campo en la alimentación de las aves. Revta Conserv. Biol. 13: 1-88.

Di Giácomo A.G. 2005. Aves de la Reserva El Bagual, pp. 201465. In: Di Giácomo A.G. \& Krapovickas S.F. (eds), Histori a natural y paisaje de la Reserva El Bagual, Formosa, Argentina. Inventario de la fauna de vertebrados y de la flora vascular de un área del Chaco Húmedo, Temas de Naturaleza y Conservación, 4, Aves Argentinas / Asociación Ornitológica del Plata, Buenos Aires, 592 pp.

Di Iorio O., Turienzo P., Nava S., Mastropaolo M., Mangold A.J., González Acuña D. \& Guglielmone A.A. 2010. Asthenes dorbignyi (Reichenbach) (Passeriformes: Furnariidae) host of $A r$ gas neghmei Kohls \& Hoogstraal, 1961 (Acari: Argasidae). Exp. Appl. Acarol. 51 (4): 419-422. DOI: 10.1007/s10493009-9333-4

Dobbs R.C., Greeney H.F. \& Martin P.R. 2003. The nest, nesting behavior, and foraging ecology of the rusty-winged barbtail (Premnornis guttuliger). Wilson Bull. 115 (4): 367-373. DOI: $10.1676 / 03-033$

Dow D.D. 1965. The role of saliva in food storage by the gray jay. Auk 82 (2): 139-154.

Duke G.E. 1977. Pellet egestion by a captive Chimney Swift (Chaetura pelagica). Auk 94 (2): 385.

Elpers M.J. \& Knight J.B. 2007. Pellet-casting by a western scrub-jay. Western Birds 38 (3): 219-221.

Emblen D.L. 1954. Caspian terns nesting at San Diego Bay. Condor 56: 109-110.

Escola B.F.E. \& Calchi R. 2009. Nido y selección del sitio del nido del albañil (Furnarius leucopus) en un ambiente agropecuario, Barranquitas, Zulia, Venezuela. Boletín del Centro de Investigaciones Biológicas (Universidad del Zulia, Maracaibo) 43 (2): 245-262.

Fjeldså J. \& Krabbe N. 1990. Birds of the High Andes. Zoological Museum, University of Copenhagen \& Apollo Books. Copenhagen, Svendborg, 880 pp. ISBN: 87-88757-16-1.

Fisher W.K. 1904. On the habits of the Laysan albatross. Auk 21 (1): 8-20. DOI: $10.2307 / 4069919$

Fraga R. 1980. The breeding of rufous Horneros (Furnarius rufus). Condor 82 (1): 58-68.

Glue D. 1973 Owl pellets, pp. 193-196. In: Burton J.A. (ed.) Owls of the world: Their Evolution, Structure and Ecology, Peter Lowe, London, 212 pp ISBN: 0856546038, 9780856546037

Glue D.E. 1985. Pellet, pp. 443-444. In: Campbell B. \& Lack E. (eds), Dictionary of Birds, Buteo Books, Vermillion, SD, 670 pp. ISBN: 0931130123, 9780931130120

Gonzalez-Solos J., Oro D. \& Pedrocchi V. 1997. Bias associated with diet samples in Audouin's gulls. Condor 99 (3): 713719.

Greeney H.F. 2008. The Spotted Barbtail (Premnoplex brunnescens): a review of taxonomy, distribution, and breeding biology, with additional observations from northeastern Ecuador. Boletín SAO (Sociedad Antioqueña de Ornitología) 18 (1): $1-9$.

Haro J.G. 1998. Alimentación de aves insectívoras en un bosque de coníferas en Río de los Sauces (Córdoba, Argentina). Revta Natura Neotrop. 29 (2): 117-125. DOI: 10.14409/natura.v2i29.3730

Heredia J., Moller Jensen R., Figuerero C. \& La Grotteria J. 2010. Cuatro Furnariidae "pescando": Hornero (Furnarius rufus), Curutié Colorado (Certhiaxis cinnamomea), Remolinera Castaña (Cinclodes atacamensis) y Remolinera Chocolate (Cinclodes olrogi). Nuestras Aves 55: 17-19.

Higes M., Martín-Hernández R., Garrido-Bailón E., Botías C., García-Palencia P. \& Meana A. 2008. Regurgitated pellets of Merops apiaster as fomites of infective Nosema ceranae (Microsporidia) spores. Envir. Microbiol. 10 (5): 1374-1379. DOI: $10.1111 / j .1462-2920.2007 .01548 . x$

Hoffmann R. 1920. A raven pellet. Auk 37 (3): 453-454. DOI: $10.2307 / 4073277$

Holt P. \& Warrington S. 1996. The analysis of faeces and regurgitated pellets for determining prey size: problems and bias illustrated for Green Sandpipers Tringa ochropus feeding on Gammarus. Wader Study Group Bull. 79: 65-68.

Hothorn T., Hornik K., van de Wiel M.A. \& Zeileis A. 2008. Implementing a class of permutation tests: the coin package. J. Stat. Software 28 (8): 1-23.

Jakubas D. \& Mioduszewska A. 2005. Diet composition and food consumption of the grey heron (Ardea cinerea) from breeding colonies in northern Poland. Eur. J. Wildl. Res. 51 (3): 191198. DOI: $10.1007 / \mathrm{s} 10344-005-0096-\mathrm{x}$

Jehl Jr. J.R. 1988. Biology of the eared grebe and Wilson's phalarope in the nonbreeding season: a study of adaptations to saline lakes. Stud. Avian Biol. 12: 1-74. ISBN: 0-93586839-9-9

Johnstone I.G., Harris M.P., Wanless S. \& Graves J.A. 1990. The usefulness of pellets for assessing the diet of adult Shags Phalacrocorax aristotelis. Bird Study 37 (1): 5-11. DOI: 10.1080/00063659009477030

Jonczyk P. 2009. Malachite Kingfisher Alcedo cristata. In: The Internet Bird Collection. http://ibc.lynxeds.com/photo/ malachite-kingfisher-alcedo-cristata/bird-regurgitating-pelletundigested-food (accessed 14.02.2011)

Jordan M.J.R 2005. Dietary analysis for mammals and birds: a review of field techniques and animal-management applications. Int. Zool. Yearbook. 39 (1): 108-116. DOI: 10.1111/j.1748-1090.2005.tb00010.x

Keller T. 1998. Die Nahrung von Kormoranen (Phalacrocorax carbo sinensis) in Bayern. J. Omithol. 139 (4): 389-400. DOI: $10.1007 / \mathrm{BF} 01653465$

Kelvin S.-H.P. \& Sodhi N.S. 2002. Characteristics of nocturnal roosts of house crows in Singapore. J. Wildl. Manage. 66 (4): 1128-1133.

Klimaitis J.F. 1993. Contenido estomacal de algunas aves. Municipalidad de Berisso, Dirección de Cultura, Museo Ornitológico Municipal de Berisso, Publicación 3: 1-8.

Kurosawa R., Kono R., Kondo T. \& Kanai I. 2003. Diet of jungle crows in an urban landscape. Global Environ. Res. 7 (2): 193-198.

Lamore D.H. 1958. Production of pellets by a Blue Jay. Wilson Bull. 70 (4): 381.

Laskey A.R. 1944. A study of the cardinal in Tennessee. Wilson Bull. 56 (1): 27-44.

Lehmann F.C. 1959. Observations on the cattle egret in Colombia. Condor 61 (4): 265-269.

Lopes L.E., Fernandes A.M. \& Marini M.A. 2003. Consumption of vegetable matter by Furnarioidea. Ararajuba 11 (2): 235239.

Lopes L.E., Fernandes A.M. \& Marini M.A. 2005a. Diet of some Atlantic forest birds. Ararajuba 13 (1): 95-103.

Lopes L.E., Fernandes A.M. \& Marini M.A. 2005b. Predation on vertebrates by Neotropical passerine birds. Lundiana 6 (1): 57-66.

Magrath M.D., Platzen D. \& Kondo J. 2006. From nestling calls to fledgling silence: adaptive timing of change in response to aerial alarm calls. Proc. Roy. Soc. Biol. 273 (1599): 23352341. DOI: $10.1098 / \mathrm{rspb} .2006 .3610$

Maher W.J. 1970. Ecology of the long-tailed jaeger at Lake Hazen, Ellesmere Island. Arctic 23 (2): 112-129. DOI: http://dx.doi.org/10.14430/arctic3162

Malacalza V.E., Poretti T.I. \& Sertellotti N.M. 1994. La dieta de Phalacrocorax albiventer en Punta Leon (Chubut, Argentina) durante la temporada reproductiva. Ornitol. Neotrop. 5: 9197 . 
Malzof S.L. \& Quintana R.D. 2008. Diet of the south polar skua Catharacta maccormicki and the brown skua C. antarctica lonnbergi at Cierva Point, Antarctic Peninsula. Polar Biol. 31 (7): 827-835. DOI: 10.1007/s00300-008-0421-4

Marelli C.A. 1919. Sobre el contenido del estómago de algunas aves. El Hornero 1 (4): 221-228.

Mason E.A. 1943. Northern shrike regurgitates pellet. J. Field Ornithol./ Bird Banding 14 (1-2): 46.

Matsuoka S. 1986. Pellet regurgitation by great spotted Dendrocopos major and white-backed woodpeckers D. leucotos. Jap. J. Ornithol. 35: 75-76. DOI: 10.3838/jjo.35.75

Maunder J.E. \& Threlfall W. 1972. The breeding biology of the black-legged kittiwake in Newfoundland. Auk 89 (4): 789 816.

McCaskie R.G., Stallcup R. \& DeBenedictis P. 1967. The occurrence of certain flycatchers in California. Condor $\overline{69}(\overline{\mathbf{1}})$ : 85-86.

McFarland R.W. \& Loo E. 1974. Food habits of some birds in Tarapacá. Idesia 3: 163-166.

Meanley B. 1955. A nesting study of the little blue heron in eastern Arkansas. Wilson Bull. 67 (2): 84-99.

Meanley B. 1962. Pellet casting by king and clapper rails. Auk 79 (1): 113.

Mewaldt L.R. 1957. Recent literature. Bird Banding 28 (1): 4155.

Moojen J., Carvalho J.C. de \& Souza Lopes H. de 1941. Observações sobre o conteúdo gastrico das aves brasileiras. Mem. Inst. Oswaldo Cruz 36 (3): 405-444.

Mužinic J. \& Rašajski J. 1992. On food and feeding habits of the White Stork, Ciconia c. ciconia, in the Central Balkans. Ecol. Birds 14: 211-223

Narosky T., Fraga R. \& De la Peña M. 1983. Nidificación de las aves argentinas (Dendrocolaptidae y Furnariidae). Asociación Ornitológica del Plata, Buenos Aires, 98 pp.

Narosky T. \& Yzurieta D. 2003. Guía para la identificación de las aves de Argentina y Uruguay. Vazquez Mazzini Editores, Buenos Aires, 346 pp. ISBN: 9879132068, 9789879132067

Naves L.C. \& Vooren C.M. 2006. Diet of black skimmers in southern Brazil. Waterbirds 29 (3): 335-344.

Nores A.I. 1993. Comportamiento social de dos especies de furnaridos leñateros. Tesis Doctoral en Ciencias Biológicas. Universidad Nacional de Córdoba, Facultad de Ciencias Exactas, Físicas y Naturales, 160 p. [library \# B-117]

Nores A.I. \& Nores M. 1994. Nest building and nesting behavior of the Brown Cachalote. Wilson Bull. 106: 106-120.

Nuttall T. 1832. Manual of the Ornithology of the United States and Canada. The Land Birds. Vol. 1, E.W. Metcalf and Company, Cambridge, 683 pp.

Oberlander G. 1939. The history of a family of black phoebes, with three illustrations. Condor 41 (4): 133-151.

Olrog C.C. 1956. Contenidos estomacales de aves del noroeste argentino. El Hornero 10 (2): 158-163.

Ohlson J.I., Irestedt M., Ericson P.G.P. \& Fjeldså J. 2013. Phylogeny and classification of the New World suboscines (Aves, Passeriformes). Zootaxa 3613 (1): 1-35. DOI: http://dx.doi. org/10.11646/zootaxa.3613.1.1

Ordano M., Bosisio A., Boscarol B., Beltzer A. \& P. De Amsler G. 1999. Stomach contents of thirty six bird species from northern Argentina. Revista Ceres 46 (267): 555-563.

Parmalee P.W. 1952. Growth and development of the nestling crow. Am. Midl. Natur. 47 (1): 183-201. DOI: 10.2307/2421 703

Pasquier R.F. 1977. Herring Gull eating bayberry. Wilson Bull. 89 (2): 338 .

Peterson A.P. 2002. Zoonomen Nomenclatural data of Birds. iNet: Zoonomen Nomenclatural data: http://www.zoonomen. net/autax/frame.html (accessed: 19.03.2009)

Petracci P.F., Cereghetti J., Martín J. \& Obed Y.S. 2009. Dieta del biguá (Phalacrocorax olivaceus) durante la primavera en el estuario de Bahía Blanca, Buenos Aires, Argentina. El Hornero 24 (2): 73-78.

Ramo C. \& Busto B. 1993. Resource use by herons in a Yucatan wetland during the breeding season. Wilson Bull. 105 (4): $573-586$.
R Development Core Team. 2011. R: A Language and Environment for Statistical Computing. Vienna, Austria : the R Foundation for Statistical Computing. ISBN: 3-900051-070 . Available online at http://www.R-project.org/ (accessed 10.02.2011)

Reebs S.G. \& Boag D.A. 1987. Regurgitated pellets and late winter diet of black-billed magpies, Pica pica, in Central Alberta. Can. Field Natur. 101: 108-110.

Remsen Jr. J.V. 2003. Family Furnariidae (ovenbirds) pp. 162357. In: Del Hoyo J., Elliot A. \& Christie D. (eds), Handbook of the Birds of the World, Volume 8, broadbills to tapaculos, BirdLife International \& Lynx Editions, Barcelona, 845 pp. ISBN-10: 84-87334-50-4, ISBN-13: 978-84-87334-50-4

Remsen Jr. J.V., Cadena C.D., Jaramillo A., Nores M., Pacheco J.F., Perez-Emán, J. Robbins M.B., Stiles F.G., Stotz D.F. \& Zimmer, K.J. 2012. A classification of the bird species of South America. American Ornithologists' Union, South American Classification Committee. Version 11 January 2008. http://www.museum.lsu.edu/Remsen/SACCBaseline. html (accessed 11.11.2013)

Rhoades D.D. \& Duke G.E. 1975. Gastric function in a captive American bittern. Auk 92 (4): 786-792. DOI: $10.2307 / 4084789$

Richmond S.M. 1953. The attraction of purple martins to an urban location in western Oregon. Condor 55 (5): 225-249. DOI: $10.2307 / 1365035$

Sakai H.F., Ralph C.J. \& Jenkins C.D. 1986. Foraging ecology of the Hawaiian crow, an endangered generalist. Condor $\mathbf{8 8}$ (2): 211-219. DOI: $10.2307 / 1368918$

Sánchez M.I., Green A.J., Amat F. \& Castellanos E.M. 2007. Transport of brine shrimps via the digestive system of migratory waders: dispersal probabilities depend on diet and season. Marine Biol. 151: 1407-1415. DOI: 10.1007/s00227006-0577-9

Schubart O., Aguirre A.C. \& Sick H. 1965. Contribuição para o conhecimento da alimentaçăo das aves brasileiras. Arquivos de Zoologia (São Paulo) 12: 95-249.

Sears H.F. 1978. Nesting behavior of the gull-billed tern. BirdBanding 49 (1): 1-100. DOI: 10.2307/4512314

Sick H. 2001. Ornitología Brasileira. Editora Nova Frontera (3S impressao). Rio de Janeiro, 912 pp. ISBN: 85-209-0816-0

Stiehl R.B. \& Trautwein S.N. 1991. Variations in diets of nesting common ravens. Wilson Bull. 103 (1): 83-92.

Storer R.W. 1978.Observations of pellet-casting by horned and pied-billed grebes. Auk 78 (1): 90-92. DOI: 10.2307/4082237

Thomas B.T. 1983. The plain-fronted thornbird: nest construction, material choice, and nest defense behavior. Wilson Bull. 95 (1): 106-117.

Thomas B.T. 1984. Maguari stork nesting: juvenile growth and behavior. Auk 101 (4): 812-823. DOI: 10.2307/4086908

Townsend C.W. 1918. A winter crow roost. Auk 35 (4): 405-416. DOI: $10.2307 / 4073214$

Trauttmansdorff J. \& Wassermann G. 1995. Number of pellets produced by immature cormorants Phalacrocorax carbo sinensis. Ardea 83 (1): 133-134.

Tucker B.W. 1944. The ejection of pellets by passerine and other birds. British Birds 38: 50-52.

Turienzo P. \& Di Iorio O.R. 2008a. Insects found in birds' nests from Argentina. Anumbius annumbi (Vieillot, 1817) [Aves: Furnariidae]. Zootaxa 1871: 1-55.

Turienzo P. \& Di Iorio O. 2008b. Buscando insectos en nidos de aves. Biologica (Santa Fe) 4: 6-11.

Turienzo P. \& Di Iorio O.R. 2010. Insects found in birds' nests from Argentina. Furnarius rufus (Gmelin, 1788) (Aves: Furnariidae) and their inquiline birds, the true hosts of Acanthocrios furnarii (Cordero \& Vogelsang, 1928) (Hemiptera: Cimicidae). Zootaxa (Monograph) 2700: 1-112.

Turienzo P. \& Di Iorio O. 2011. Insects found in birds' nests from Argentina. Myiopsitta monachus (Boddaert, 1873) (Aves: Psittacidae), exclusive host of Psitticimex uritui (Lent \& Abalos, 1946) (Hemiptera: Cimicidae). Zootaxa 3053: 1-58.

Turienzo P. \& Di Iorio O. 2013. Insectos en nidos de aves de la Argentina: Asthenes dorbignyi (Reichenbach, 1853) (Aves: Furnariidae). Idesia 31 (4): 87-94. DOI: http://dx.doi.org/ $10.4067 /$ S0718-34292013000400012 
Turienzo P. \& Di Iorio O.R. 2014. Insects in birds' nests from Argentina. Pseudoseisura lophotes Reichenbach, 1853 and Anumbius annumbi (Vieillot, 1817) (Aves: Furnariidae), hosts of Triatoma platensis Neiva, 1913 (Hemiptera: Reduviidae: Triatominae). Zootaxa 3766: 1-82. DOI: 10.11646/zootaxa.3766.1.1.

Twedt D.J. 1984. Pellet casting by common grackles. Wilson Bull. 96 (3): 470-471.

Vlaming V.L. de 1967. Regurgitation by killdeer as a possible means of dispersal for seeds and aquatic organisms. Wilson Bull. 79 (4): 449-450.

Votier S.C., Bearhop S., MacCormick A., Ratcliffe N. \& Furness R.W. 2003. Assessing the diet of great skuas, Catharacta skua, using five different techniques. Polar Biol. 26: 20-26. DOI: 10.1007/s00300-002-0446-z

Wagner H.O. 1946. Food and feeding habits of Mexican hummingbirds. Wilson Bull. 58 (2): 69-93.

Wang L.K., Chan M., Chan Y.M., Tan G.G \& Wee W.C. 2009. Pellet-casting by non-raptorial birds of Singapore. Nature in Singapore 2: 97-106.

Webster J.D. 1941. Feeding habits of the black oyster-catcher. Condor 43 (4): 175-180. DOI: 10.2307/1364329
Wilson R.P. \& Grémillet D. 1996. Body temperatures of freeliving African penguins (Spheniscus demersus) and bank cormorants (Phalacrocorax neglectus). J. Exp. Biol. 199 (Pt 10): 2215-2223. PMID: 8896365

Yosef R., Carrel J.E. \& Eisner T. 1996. Contrasting reactions of loggerhead shrikes to two types of chemically defended insect prey. J. Chem. Ecol. 22 (2): 173-181. DOI: 10.1007/BF02055090

Zach R. \& Falls J.B. 1977. Ejection of pellets by captive ovenbirds. Auk 94 (1): 145-146.

Zembal R. \& Fancher J.M. 1988. Foraging behavior and foods of the light-footed clapper rail. Condor 90 (4): 959-962. DOI: $10.2307 / 1368864$

Zotta A. 1936. Sobre el contenido estomacal de aves argentinas. El Hornero 6: 261-270.

Zotta A. 1940. Lista sobre el contenido estomacal de las aves argentinas. El Hornero 7 (3): 402-411.

Zyskowski K. \& Prum R.O. 1999. Phylogenetic analysis of the nest architecture of Neotropical ovenbirds (Furnariidae). Auk 116 (4): 891-911. DOI: $10.2307 / 4089670$

Received July 11, 2013 Accepted August 2, 2014 